\title{
"THE EMERGENCE OF FREE INTERVALS IN THE TRAFFIC FLOW DEPENDING ON THE INTENSITY OF MOVEMENT AND SPEED"
}

\section{ПОЯВА ВІЛЬНИХ ІНТЕРВАЛІВ В ТРАНСПОРТНОМУ ПОТОЦІ В ЗАЛЕЖНОСТІ ВІД ІНТЕНСИВНОСТІ ТА ШВИДКОСТІ РУХУ}

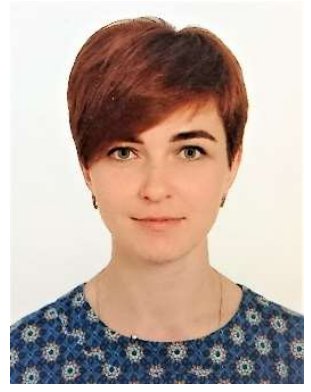

Sokolenko Tetiana Viktorivna, research assistant M.P. Shulgin State Road Research Institute State Enterprise.

https://orcid.org/0000-0003-1485-2717.

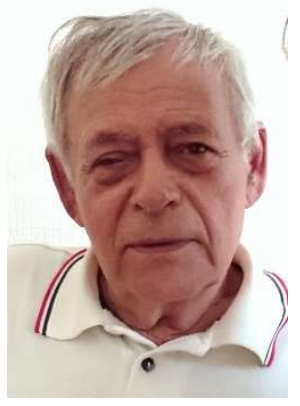

Palchyk Anatoliy Mykolayovych CTS, Docent., Professor at the Department of Road Design, Geodesy and Land Management. National Transport University.

https://orcid.org/0000-0002-7658-6066

Summary: The movement of single and group cars in traffic flows was investigated during the work. These studies are used to calculate the vehicle delay time during maneuvers through crossings and adjacencies at the same level. On the basis of the data obtained, the technical and economic discussion of the cross-sectional or adjoining parameters under consideration can be made.

In the course of the study, examination will be conducted on the influence of intensity, velocity and traffic flow on the distribution intervals between cars and a graph of this effect for different traffic intensities is to be constructed. On the basis of the provided charts, the dependence of the free interval, necessary for maneuvering, on the traffic flow intensity is described. Using this dependence, you can figure out the number of cars that can be transported continuously.

Knowing the traffic flow, its intensity and the distribution of free intervals between cars and groups of vehicles, the lag time of cars that are waiting for the ability to maneuver as well as their quantity can be calculated with the help of the proposed method.

Keywords: traffic Intensity, free interval, interchange, vehicle, group of cars, road.

Introduction. The behavior of vehicles affects the behavior of drivers. A separate driver, trying to achieve his own optimal solution, conflicts with others who interact with him by means of overtaking, switching lanes and changing the itinerary on a straight section of the road. By performing a maneuver on the intersection of the crossing or adjoining of highways, the main problem of interaction between drivers is the expectation by the vehicle of the possibility of maneuvering. Thus, there is a need to study the interaction of traffic flows driven by the main and secondary roads to address the problems associated with the loss of time and long-term expectations. 
Purpose and methods: After investigating the distribution of free intervals between cars in the traffic flow, it is possible to calculate the length of waiting time for cars to maneuver. The time required to perform a maneuver depends not only on the type and geometric parameters of intersection or adjacency, but also on the length of free intervals and the duration of the group of cars and consists of time for the implementation of the actual maneuver itself, the duration of the free interval between groups of vehicles moving on the main road and the duration of the group of cars, the interval between which is less than the required maneuver.

Given the dependence of the distribution of free intervals in the traffic flow on the intensity of traffic and the composition of the traffic flow on the main and secondary roads, it is possible to create a model of behavior of vehicles in the course of maneuver on crossing or adjoining and to consider such models for different intensities and different types of transport solutions in one level . Further, these data may be used for a feasibility study of changing the parameters of transport solutions at one level.

Results and explanation. Having examined the traffic flow of motorways in the locations of transport interchanges in one level, a number of parameters such as traffic intensity, speed, traffic flow composition, intervals between single and groups of cars, the number of vehicles in the group were recorded and processed for further use in calculations. On the basis of the processed data the regularity of the traffic of vehicles and the distribution of free intervals depending on the intensity of the movement are deduced.

Research at a different intensity of movement is given for an intensity of 458 cars / hour, as an example. (Table 1, Fig.1)

Table 1- Frequency of occurrence of a free interval of a given length in a traffic flow, moving with traffic intensity $\mathrm{N}=458$ cars / hour.

Таблиця 1- Частота появи вільного інтервалу заданої довжини в транспортному потоці, що рухається з інтенсивністю руху $\mathrm{N}=458$ автомобілів / годину.

\begin{tabular}{|c|c|}
\hline Duration of interval, seconds & Number of intervals, $\%$ \\
\hline $8-10$ & 30 \\
\hline $10-12$ & 23 \\
\hline $12-14$ & 17 \\
\hline $14-16$ & 8 \\
\hline $16-18$ & 6 \\
\hline $18-20$ & 7 \\
\hline $20-22$ & 7 \\
\hline $22-24$ & 2 \\
\hline
\end{tabular}

The study was conducted for intensities from 458 cars per hour to 1094 cars per hour. For each of the intensities, a diagram is constructed and a degree dependence is derived. The degree dependences for each of the intensities considered in the research are shown in Table 3.

The general function of the dependence of the appearance of a free interval for any intensity:

$$
\mathrm{n}=\mathrm{Ax} \mathrm{x}^{\mathrm{B}}
$$

where $\mathrm{n}$ - number of free intervals of given duration in percentage to total, $\%$.

$\mathrm{x}$ - duration of free interval, seconds. 


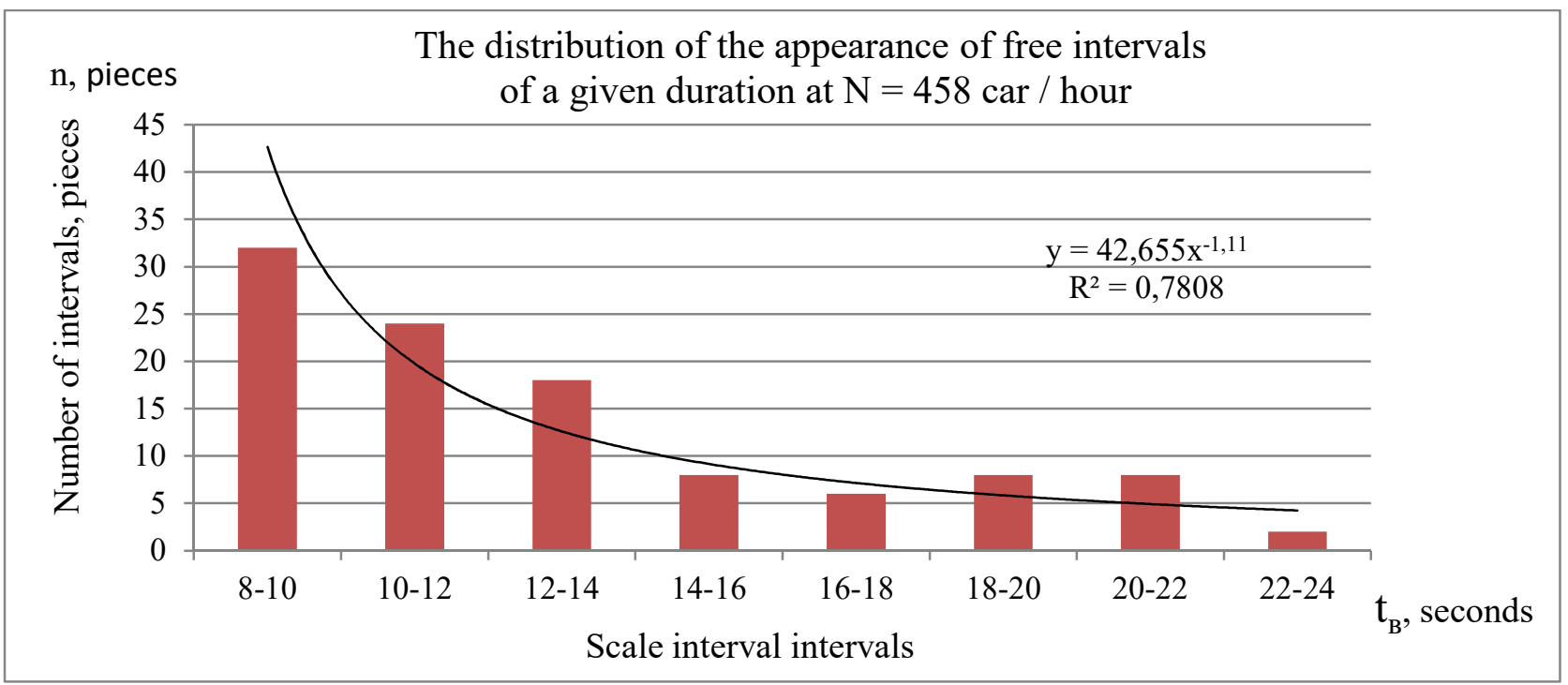

Figure_1 - The distribution diagram of the appearance of free intervals of a given duration in a traffic flow for an intensity of $\mathrm{N}=458$ cars / hour. Where $t$ is the duration of the free interval, $\mathrm{c} ; \mathrm{n}$ - number of free intervals of a given duration, pcs.

Рисунок 1 - Діаграма розподілу появи вільних інтервалів заданої тривалості в транспортному потоці для інтенсивності $\mathrm{N}=458$ автомобілів / годину. Де $\mathrm{t}$ - тривалість вільного інтервалу, с; $\mathrm{n}$ - кількість вільних інтервалів заданої тривалості, шт.

Table 2 - General table of the dependence of the number of free intervals of a given duration on the traffic intensity.

Таблиця 2 - Загальна таблиця залежності кількості вільних інтервалів заданої тривалості від інтенсивності руху.

\begin{tabular}{|c|c|c|c|c|c|c|c|c|c|c|c|c|}
\hline \multirow{2}{*}{$\mathbf{t}_{\mathbf{B}, \text { sec }}$} & \multicolumn{10}{|c|}{ Intensity of vehicles in 1 lane of traffic in 1 direction, cars / hour } \\
\cline { 2 - 16 } & 458 & 704 & 730 & 732 & 746 & 820 & 850 & 856 & 934 & 980 & 1094 & 1140 \\
\hline 1 & 2 & 3 & 4 & 5 & 6 & 7 & 8 & 9 & 10 & 11 & 12 & 13 \\
\hline $8-10$ & 32 & 56 & 16 & 40 & 42 & 22 & 52 & 54 & 18 & 10 & 10 & 12 \\
\hline $10-12$ & 24 & 36 & 24 & 20 & 34 & 26 & 26 & 34 & 10 & 16 & 18 & 4 \\
\hline $12-14$ & 18 & 8 & 8 & 18 & 20 & 12 & 12 & 8 & 6 & 2 & 6 & 2 \\
\hline $14-16$ & 8 & 16 & 10 & 8 & 6 & 8 & 8 & 6 & 4 & 2 & 6 & 8 \\
\hline $16-18$ & 6 & 6 & 8 & 6 & 12 & 4 & 4 & 10 & 2 & 6 & 4 & 4 \\
\hline $18-20$ & 8 & 4 & 4 & 16 & 6 & 4 & 2 & 6 & 0 & 1 & 4 & 2 \\
\hline $20-22$ & 8 & 4 & 6 & 4 & 4 & 4 & 2 & 2 & 0 & 4 & 2 & 2 \\
\hline $22-24$ & 2 & 1 & 2 & 8 & 2 & 6 & 0 & 4 & 0 & 1 & 0 & 4 \\
\hline
\end{tabular}




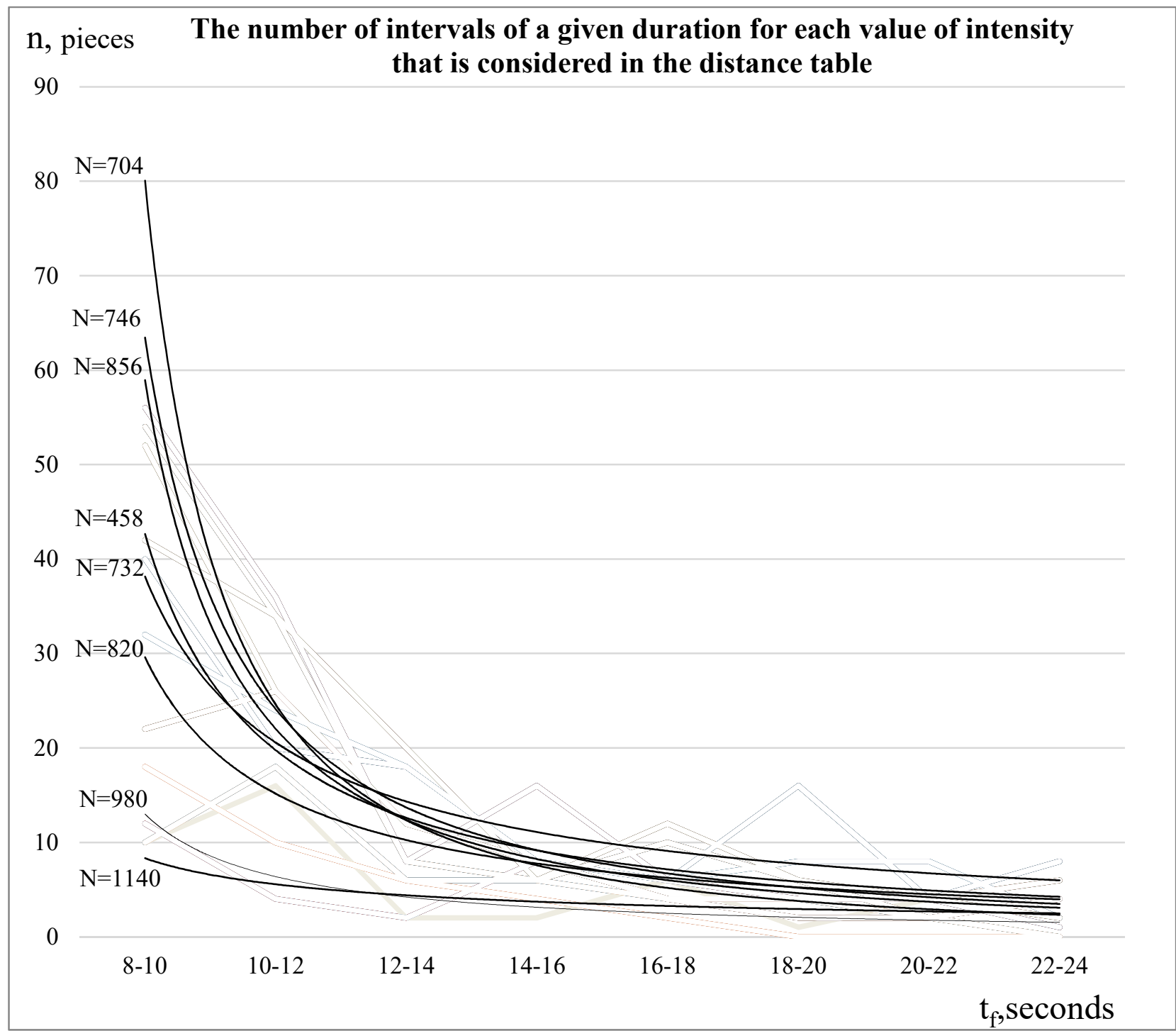

Figure 2 - Graph of the number of intervals of the given duration for each intensity value, which was considered in the study. Where $t_{f}$ is the duration of the free interval, seconds; $n$ - the number of free intervals of a given length, pieces; $\mathrm{N}$ - traffic intensity, cars / hour.

Рисунок 2 - Графік кількості інтервалів заданої тривалості для кожного значення інтенсивності, яке враховувалось у дослідженні. Де tf - тривалість вільного інтервалу, секунд; n - кількість вільних інтервалів заданої довжини, штук; $\mathrm{N}$ - інтенсивність руху, автомобілів / год. 
Table 3 - Functions of the dependence of the appearance of a free interval of a given duration for each intensity considered in the study.

Таблиця 3 - Функції залежності появи вільного інтервалу заданої тривалості для кожної інтенсивності, врахованої в дослідженні.

\begin{tabular}{|c|c|c|c|c|}
\hline $\begin{array}{c}\text { Traffic intensity N, } \\
\text { cars / hour }\end{array}$ & Dependency function & $\mathrm{R}$ & Coefficient A & Coefficient B \\
\hline 458 & $\mathrm{y}=42,655 \mathrm{x}^{-1,11}$ & $\mathrm{R}^{2}=0,7808$ & 42,655 & $-1,11$ \\
\hline 704 & $\mathrm{y}=80,069 \mathrm{x}^{-1,701}$ & $\mathrm{R}^{2}=0,8436$ & 80,069 & $-1,701$ \\
\hline 732 & $\mathrm{y}=38,149 \mathrm{x}^{-0,891}$ & $\mathrm{R}^{2}=0,6926$ & 38,149 & $-0,891$ \\
\hline 746 & $\mathrm{y}=63,474 \mathrm{x}^{-1,395}$ & $\mathrm{R}^{2}=0,8406$ & 63,474 & $-1,395$ \\
\hline 820 & $\mathrm{y}=29,617 \mathrm{x}^{-0,966}$ & $\mathrm{R}^{2}=0,7891$ & 29,617 & $-0,966$ \\
\hline 856 & $\mathrm{y}=58,969 \mathrm{x}^{-1,42}$ & $\mathrm{R}^{2}=0,8461$ & 58,969 & $-1,42$ \\
\hline 980 & $\mathrm{y}=12,995 \mathrm{x}^{-1,026}$ & $\mathrm{R}^{2}=0,4880$ & 12,995 & $-1,026$ \\
\hline 1140 & $\mathrm{y}=8,3282 \mathrm{x}^{-0,58}$ & $\mathrm{R}^{2}=0,3741$ & 8,3282 & $-0,58$ \\
\hline
\end{tabular}

Based on the data in Table 3, the graphs of the dependencies of the coefficients A and B are constructed which are shown in the figure. 3 :
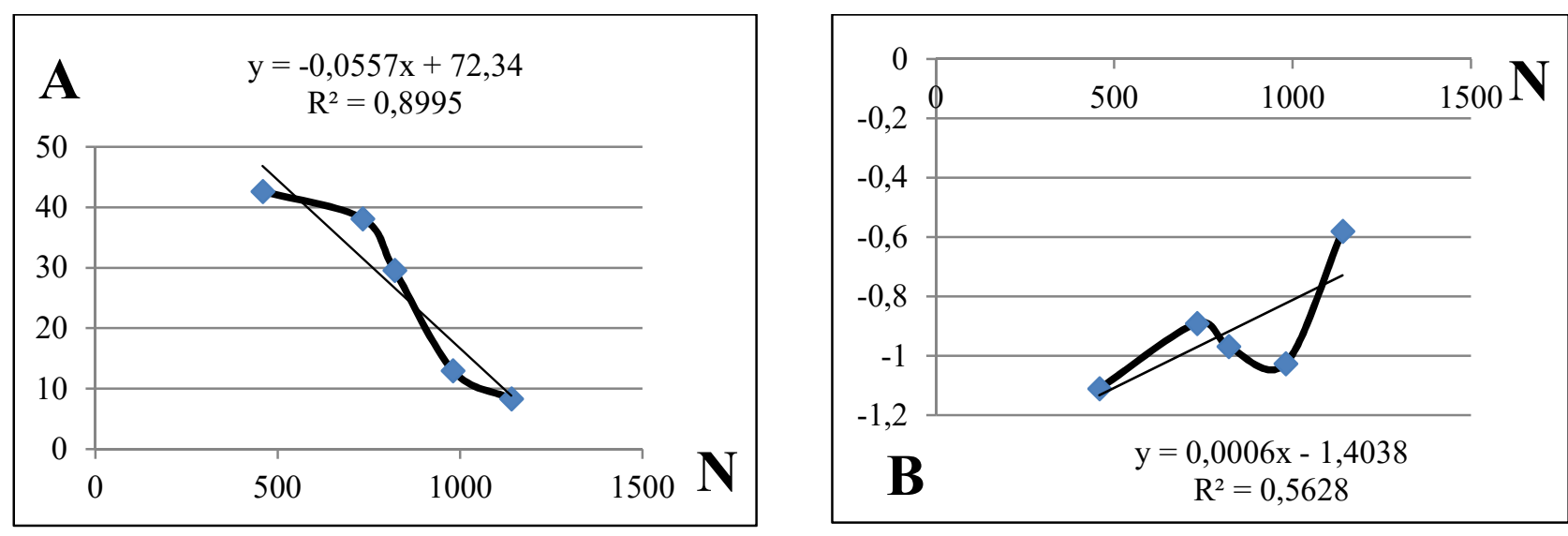

Figure 3 - The graph of the coefficient A and coefficient B dependence on the traffic intensity N.

Рисунок 3 - Графік залежності коефіцієнта А та коефіцієнта В від інтенсивності руху N

On the basis of the data in Table 3, the dependence functions of coefficients A and B are determined:

$$
\begin{aligned}
& A=-0,0557 x+72,34 \\
& B=0,0006 x-1,4038
\end{aligned}
$$

The number of free intervals of a given length can be determined by substituting the intensity of the traffic on the strip and setting the required interval for the maneuver between cars or groups of vehicles.

$$
\mathrm{n}=\mathrm{A} \cdot \mathrm{t}_{\mathrm{B}}{ }^{\mathrm{B}}
$$

By substituting the values of the previously determined coefficients $A$ and $B$, the equation is obtained: 


$$
\mathrm{n}=(-0,0557(\mathrm{~N})+72,34) \cdot\left(\mathrm{t}_{\mathrm{B}}\right)^{0,0006(\mathrm{~N})-1,4038}
$$

where, $\mathrm{n}$ - number of intervals of the given duration in the traffic flow;

$\mathrm{N}$ - intensity of traffic along the lane, cars / hour;

$t_{f}-$ the duration of the free interval, seconds.

Check the equation with the actual data for intensity $\mathrm{N}=1140$ cars / hour and for the duration of the free interval of 20 seconds:

$$
\mathrm{n}=(-0,0557(1140)+72,34) \cdot(20)^{0,0006(1140)-1,4038}=8,842 \cdot 20^{-0,72}=2 \text { pieces }
$$

Conclusion: After examining the model of behavior of vehicles in carrying out the maneuver on crossing or adjoining and considering such models for different intensities and different types of transport solutions in one level, we obtained an equation by which one can determine the number of free intervals of a given length for any intensity of motion.

Given the dependence of the distribution of free intervals in the traffic flow on the intensity of traffic and the composition of the traffic flow on the main and secondary roads, it is possible to calculate the number of vehicles that can perform maneuver on the intersection or adjacency.

On the basis of this data, it will be possible to carry out a feasibility study on changing the geometric parameters of transport solutions in one level.

\section{References}

1. VA Hoffman, VM Vizgalov, MP Polyakov. Crossing and adjoining roads. - M.: Higher school, 1989. $-319 p$.

2. Crossing and adjoining roads in one level. Methods of designing and organizing traffic. VBN V.2.3218-192-2005. Ukravtodor K., 2005.

3. Keit F. Mathematical theory of transport flows. Moscow, Mir Publ., 1966.

4. Polishchuk VP, Dzyuba O.P. The theory of transport flow: methods and models of road traffic organization / VP Polishchuk, O.P. Dzyuba - K .: Knowledge of Ukraine, 2008. - 175 p.

5. Drew D. The theory of transport flows and their management. M .: Transport, 1972. - $424 \mathrm{p}$.

6. Polishchuk VP The theory of traffic flow: methods and models of traffic organization: teaching. manual / VP Polishchuk, O.P. Dzyuba - K .: Knowledge of Ukraine, 2008. - P. 49 - 169.

7. Designing and searching of intersections of highways / [E.M. Lobanov, V.M. Shevyakov, VA Gohman and others]. - M .: Transport, 1972. - P. 40-84.

8. Palchik AM Transport streams / Palchik AM - K .: NTU, 2010. - P. 26-42, 44-47, 52-54, 87-102.

\section{ПОЯВА ВІЛЬНИХ ІНТЕРВАЛІВ В ТРАНСПОРТНОМУ ПОТОЦІ В ЗАЛЕЖНОСТІ ВІД ІНТЕНСИВНОСТІ ТА ШВИДКОСТІ РУХУ}

Соколенко Тетяна Вікторівна, молодший науковий співробітник Державне підприємство «Державний дорожній науково-дослідний інститут імені М.П.Шульгіна», https://orcid.org/0000-0003-1485-2717. Пальчик Анатолій Мколайович, к.т.н., доцент, професор кафедри проектування доріг, геодезії та землеустрою, https://orcid.org/0000-0002-7658-6066 
Анотація: Під час виконання роботи було досліджено рух одиночних та груп автомобілів у транспортному потоці, закономірність появи вільних інтервалів між транспортними засобами, що рухаються головною дорогою, залежність можливості виконання маневру на перехрещенні чи примиканні від тривалості руху групи автомобілів та тривалості вільного інтервалу між цими групами. Дані дослідження використовуються для розрахунку часу затримки транспортних засобів під час виконання маневрів на перехрещення та примиканнях в одному рівні. На основі отриманих даних можливо буде виконати техніко-економічне обгрунтування параметрів перехрестя чи примикання, що розглядається.

В ході виконання дослідження було розглянуто вплив інтенсивності, швидкості руху та складу транспортного потоку на розподіл інтервалів між автомобілями та побудовано графіки залежності цього впливу для різної інтенсивності руху. На основі побудованих графіків виведено залежність появи вільного інтервалу, необхідної тривалості для виконання маневру, від інтенсивності руху транспортного потоку. Використовуючи цю залежність можна буде розрахувати кількість автомобілів які зможуть безперешкодно виконати маневр.

Знаючи склад транспортного потоку, його інтенсивність та закономірність розподілу вільних інтервалів між автомобілями та групами автомобілів, за допомогою запропонованого методу можливо буде розрахувати як час затримки автомобілів що очікують можливості виконання маневру так і їх кількість.

Ключові слова: Інтенсивність руху, вільний інтервал, розв'язка, транспортний засіб, група автомобілів, автомобільна дорога.

\section{Перелік посилань}

1. В. А. Гофман, В. М. Визгалов, М. П. Поляков. Пересечения и примыкания автомобильных дорог. - М. : Высшая школа, 1989. - 319 с.

2. Перехрещення та примикання доріг в одному рівні. Методи проектування та організації дорожнього руху. ВБН В.2.3-218-192-2005. Укравтодор. К., 2005.

3. Хейт Ф. Математическая теория транспортных потоков. М.: Мир, 1966. — 288 с.

4. Поліщук В.П., Дзюба О.П. Теорія транспортного потоку: методи та моделі організації дорожнього руху / В.П. Поліщук, О.П. Дзюба. - К.: Знання України, 2008. - 175 с.

5. Дрю Д. Теория транспортных потоков и управление ими. М.: Транспорт, 1972. -424 с.

6. Поліщук В.П. Теорія транспортного потоку: методи та моделі організації дорожнього руху : навч. посіб. / В.П. Поліщук, О.П. Дзюба. - К.: Знання України, 2008. - С. 49 - 169.

7. Проектирование и изыскание пересечений автомобильных дорог / [ Е.М. Лобанов, В.М. Шевяков, В.А. Гохман и др. ]. - М.: Транспорт, 1972. - С. 40-84.

8. Пальчик А.М. Транспортні потоки / Пальчик А.М. - К.: НТУ, 2010. - С. 26-42, 44-47, 52-54, $87-102$. 